\title{
Experimental Study on Soil Stabilization Using Fibres
}

\author{
B. Priyadharshini ${ }^{1, a^{*}}$, Boopathiraj $^{1, b}, P$. Eshanthini ${ }^{1, c}$ \\ ${ }^{1}$ Department of civil engineering, Sathyabama Institute of Science and Technology, Chennai, \\ India \\ a*dharspriya@gmail.com, bboopathiraj1964@gmail.com, ceshaindia14@gmail.com
}

\begin{abstract}
Keywords: Bearing Capacity, CBR Test, Fine-Grained Soil, Fibres, Stabilization, Unconfined Compression, Unreinforced Sample
\end{abstract}

\begin{abstract}
For pavement constructions such as runway and highway construction, fine-grained soils are not suitable because of their undesirable properties such as grading of particle size, low bearing capacity, and more plasticity, and its ability to swell. To improve these soil properties various soil stabilization methods are needed. The stabilization is done by adding various stabilizing materials with the fine-grained soil. Fibres are one of the materials used in soil stabilization. This experimental study has been carried over to improve the bearing capacity of soft soil (from Sholinganallur, Chennai) by using Natural and Artificial fibres. During this study, the soil samples which has been stabilized with various fibres was prepared i.e., soil with Natural fibres (jute fibre) and soil with artificial fibres. In this experimental study, index properties and engineering properties of soft soil or unreinforced samples and stabilized soil samples with fibres are determined. Samples are subjected to various soil tests which have been used to determine the engineering properties of soil. The soil tests such as the standard proctor compaction test, unsoaked California Bearing Ratio (CBR) test, and Unconfined Compression (UCC) test had been done to determine the characteristics of the samples. To determine the properties of the reinforced materials, the fibres also have undergone various geosynthetic laboratory tests. The results of the study show that the bearing capacity of Shollinganallur fine-grained soil can be improved subsequently and water absorption by soil has been reduced significantly by using fibres.
\end{abstract}

\section{Introduction}

The fine-grained soils have low strength and high compressibility, building highways and runways over them is one of the most common civil engineering problems encountered in various parts of the world. [1]. So, Roads should be constructed on strong native soil deposits and the behaviour of the road surface depends upon the strength of the base material and the subgrade below it or the fine-grained soils are needed to be stabilized to attain a required strength of pavement [2]. Fine-grained soil is described as soil with a California Bearing Ratio (CBR) of less than $8 \%$ and an Unconfined Compressive Strength (UCS) of less than $48 \mathrm{kPa}$ that requires stabilization, especially in pavement applications, to improve its properties. The standard method for building a highway or runway on fine-grained soils is to excavate the soft soil layer and then substitute it with a stabilizing material such as geosynthetics, crushed rock, or other similar materials., The high cost of transporting soil makes higher authorities establish the alternate solution of construction of structures on fine-grained soils and new techniques of stabilization [3]. Stabilization is important to increase the strength of the base layer based on that the base course gravel layer can be constructed. Stabilization is being used for many engineering works, the common application being in the construction of pavements such as road and airfield pavements, where the aim is to increase the bearing capacity or strength of fine-grained soil and to reduce the construction cost [4][5]. The pavement is supported by subgrade soil and which helps the foundation to carry a load 
and for this purpose, an appropriate value of California bearing ratio (CBR) is required for subgrade soil to ensure required strength to support the imposed load came from traffic, regardless adverse conditions such as high rainfall and flooding. Some of the subgrade soils are not able to meet these criteria because of lower and inappropriate CBR values [6]. The geosynthetics which have been most commonly used in the construction field are geosynthetic clay liners, geomembranes, geogrids, fibres, geonets, geocomposite drainage materials, erosion control blankets, and materials [7]. The word 'Geo synthetics' has two parts in it, the 'geo' indicates an increase in the stability of civil engineering works including earth or ground or soil and the 'synthetics' indicates the man-made products. synthetic polymers are used to manufacture geosynthetics which are commonly derived from crude petroleum oils, rubber [8]. Sometimes other materials apart from the oils, rubber is also used for the manufacturing of geosynthetics. The major functions of geosynthetic materials, related to civil engineering are drainage reinforcement, separation, filtration, and acting as a liquid barrier. Fibres is one of the geosynthetic materials used to improve the stability of soil [9]. Fibres are used in flexible pavement systems for separation and reinforcement purposes which have been obtained from planar polymeric materials and for many years, the fibres are used in the construction of road works, which has been acting as a separator in the area of stabilization [10][11]. This is the major application of fibres. Natural and synthetic (artificial) fibres are usually graded based on their material composition. Natural fibres such as jute fibre (Geojute) and coir nets are widely used and biodegradable, whereas synthetic fibres are made from synthetic polymer materials and are not biodegradable. Geojute is produced from jute plants that have been pollinated by bees [13]. Synthetic fibres are used in between the subgrade for two purposes. One is to improve the bearing capacity of subgrade and another one is to improve the efficiency of drainage. The main purpose is to the addition of these materials in soil are, the fabric reinforcement has to stay in the soil, for the entire life span of structure and also to separate the various layers or grades of soil [12]. An increase in fibre content will increase the tensile strength of the soil along with the maximum dry density and reduce the water content[15].

\section{Materials and Methodology}

This experimental study was aimed to use natural and synthetic fibres for improving the bearing capacity in fine-grained soil. Fine-grained soil samples were obtained from ponniamman temple street nearby Shollinganallur, Chennai. In this study, the fine-grained soil has alone undergone all the tests which are used to find out the soil properties. The laboratory tests such as particle size analysis, Specific gravity, Atterberg limits, Unconfined compression (UCC) test were performed on a fine-grained soil sample which is taken from the above location and shown in Table.1. Then natural fibres have been added to the soil to find out the variation in the engineering properties of soil with the use of the following tests as Direct shear test, Standard proctor compaction test, California bearing ratio (CBR) test. Again, the same procedure was repeated for synthetic (artificial) fibres. All three tests were conducted on three different samples. Results obtained from all three conditions are compared and the experiment was concluded based upon the effect of material that is used to improve the properties of soil in that fine-grained soil. 
Table 1. Properties of unreinforced soil

\begin{tabular}{|c|c|c|c|c|}
\hline S No & Test & Characteristics & Unit & Result \\
\hline \multirow[t]{2}{*}{1} & \multirow[t]{2}{*}{ Sieve test } & Sand & $\%$ & 86.8 \\
\hline & & Fine & $\%$ & 13.2 \\
\hline 2 & Direct shear test & Ultimate shear angle & Degree & $\begin{array}{l}\text { ' } 0 \text { '(for } \\
\text { cohesive soil) }\end{array}$ \\
\hline \multirow[t]{2}{*}{3} & \multirow[t]{2}{*}{ Atterberg limits } & Liquid limit (LL) & $\%$ & 32.20 \\
\hline & & $\begin{array}{l}\text { Plastic limit (PL) } \\
\text { Plasticity index ( Ip ) }\end{array}$ & $\begin{array}{l}\% \\
\%\end{array}$ & $\begin{array}{l}51.35 \\
19.15\end{array}$ \\
\hline 4 & Soil classification & USCS & - & $\begin{array}{l}\text { SC (Clayey } \\
\text { sand) }\end{array}$ \\
\hline 5 & Specific gravity Test & $\mathrm{G}_{\mathrm{s}}$ & - & 2.65 \\
\hline 6 & Standard proctor Test & $\begin{array}{l}\text { Optimum moisture } \\
\text { content }\end{array}$ & $\%$ & 12 \\
\hline 7 & Compaction Test & $\begin{array}{l}\text { Maximum dry density } \\
\left(d_{\max }\right)\end{array}$ & $\mathrm{g} / \mathrm{cc}$ & 1.894 \\
\hline \multirow[t]{2}{*}{8} & & For $2.5 \mathrm{~mm}$ & & \\
\hline & California & Penetration & $\%$ & 2.26 \\
\hline 9 & Bearing ratio test & $\begin{array}{l}\text { For } 5.0 \mathrm{~mm} \\
\text { Penetration }\end{array}$ & $\%$ & 2.92 \\
\hline
\end{tabular}

Stabilizing materials are namely natural and synthetic fibres were obtained from home and industry respectively. Synthetic fibres are light grey. Table 2 shows the properties of natural and synthetic fibres from Mahuyu Ghosh et.al.,(2014) [14]

Table 2. Properties of fibres(after Mahuya Ghosh 2009)

\begin{tabular}{clll}
\hline Type of fibres & Properties & Unit & Result \\
\hline Natural fibres & Thickness & $\mathrm{Mm}$ & 4.0 \\
& $\begin{array}{l}\text { Tensile strength } \\
\text { Bursting strength } \\
\text { (Mass/unit area } \\
\text { test) }\end{array}$ & $\mathrm{Kn}$ & 8.0 \\
The & $\mathrm{km} \mathrm{cm}^{2}$ & 0.375 \\
Synthetic fibres & $\mathrm{Mm}$ & 0.7 \\
& $\begin{array}{l}\text { Tensile strength } \\
\text { Bursting strength } \\
\text { (Mass/unit area } \\
\text { test) }\end{array}$ & $\mathrm{kN}$ & 4.20 \\
& $\mathrm{~kg} / \mathrm{cm}^{2}$ & 8.50 \\
\hline
\end{tabular}




\section{Results and Discussion}

Particle Size Analysis

The particle size distribution analysis was conducted to classify the soil sample which has been taken for experiment purpose. From the result of sieve analysis and based on the Unified soil classification system, the soil was classified as Clayey sand (SC), (refer to table-1).

Specific gravity

The specific gravity of a soil sample was determined with the use of a pycnometer. The weight of the pycnometer with various conditions are observed and the values are substituted in the specific gravity formula. The specific gravity soil sample is tabulated in table 1 . The specific gravity of clayey soil is between 2.65 to 2.67 .

\section{Atterberg Limits}

According to ASTM D4318, the Atterberg limits tests were carried out on samples, which is "Standard Test Methods for Plastic Limit (PL) and Liquid Limit (LL) of Soils". The results were obtained and the values are tabulated in Table 1.

\section{Soil Classification}

Using the result obtained by various tests such as Atterberg limits and sieve test (particle size analysis), the group symbol, i.e., According to ASTM D2487 the sample was classified from "Standard Practice for Classification of Soils for Engineering Purposes (Unified Soil Classification System)". The results were obtained are tabulated in Table 1. The classification shows that the soil sample which has been carried over from Ponniamman temple street fine-grained soil is SC (clayey sand)

\section{Unconfined compressive strength test (UCC)}

This test is used to determine the compressive strength and cohesion of the soil sample, normally it is used for cohesive soil (Fine-grained soils), during the test the lateral confining pressure is equal to zero. The UCS value indicates the compressive stress at which the cylindrical sample fails. The maximum value which was observed during the test was marked as compressive strength. For UCS test specimens (diameter greater than $30 \mathrm{~mm}$ and height to diameter ratio between 2 to 2.5), half of the value of compressive stress at failure is denoted as the cohesion of the sample. The UCS test was performed on an unreinforced soil sample and values were tabulated in Table 3 and plotted in Fig 1. The UCS value at the failure of a sample from the graph is $0.34 \mathrm{~N} / \mathrm{mm}^{2}$ and the cohesion will be half of this value which is $0.17 \mathrm{~N} / \mathrm{mm}^{2}$.

Table 3. Compressive strength and cohesion of unreinforced soil

\begin{tabular}{ccc}
\hline Properties & $\begin{array}{c}\text { Unconfined compressive } \\
\text { strength at failure }\left(\mathrm{q}_{\mathrm{u}}\right) \\
\left(\mathrm{N} / \mathrm{mm}^{2}\right)\end{array}$ & $\begin{array}{c}\text { Cohesion }(\mathrm{C}) \\
\left(\mathrm{N} / \mathrm{mm}^{2}\right)\end{array}$ \\
\hline $\begin{array}{c}\text { Unconfined } \\
\text { compression test }\end{array}$ & 0.34 & 0.17 \\
\hline
\end{tabular}




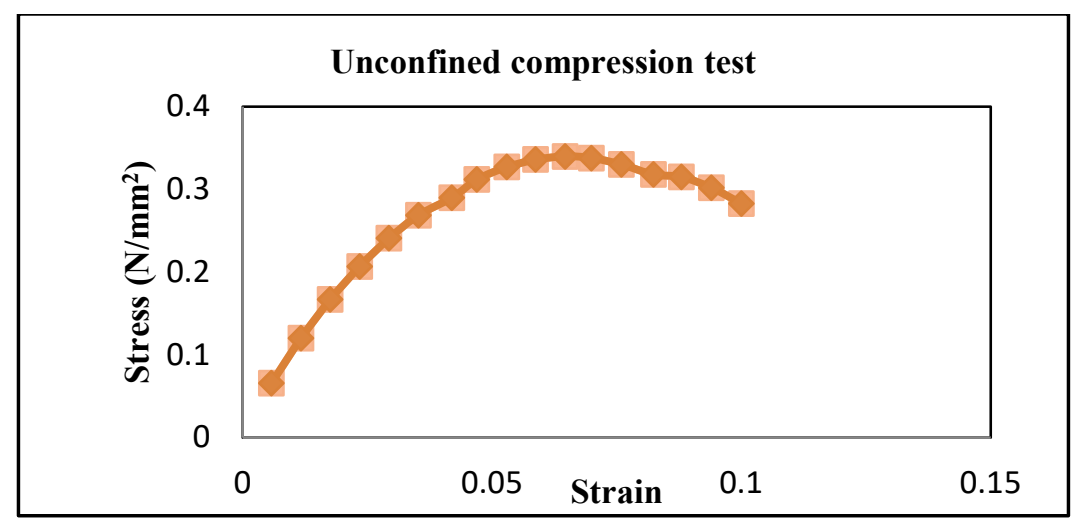

Fig 1. Compressive strength and cohesion of unreinforced soil

\section{Standard Proctor Compaction test}

According to Method A of ASTM D1557, the standard Proctor compaction tests were carried out on different samples. The fibres were laid with three layers with a soil sample to improve the stabilization. The result of these tested samples is to be used in sample preparation for the California bearing ratio tests. The results were tabulated in Table 4.The maximum dry density of the samples of the soil increases with the addition of fibres and the optimum moisture content varies between 12\% and 10\% [14].The gradual decrease in Optimum moisture content indicates that the adsorption of water by the fine-grained soil is reduced. The results were plotted in Fig 2.

Table 4. Proctor test result of different samples

\begin{tabular}{cccc}
\hline $\begin{array}{c}\text { Properties of } \\
\text { samples }\end{array}$ & $\begin{array}{c}\text { Unreinforc } \\
\text { ed soil }\end{array}$ & $\begin{array}{c}\text { Soil with } \\
\text { natural fibres }\end{array}$ & $\begin{array}{c}\text { Soil with } \\
\text { synthetic fibres }\end{array}$ \\
\hline $\begin{array}{c}\text { Optimum } \\
\text { moisture content } \\
(\%)\end{array}$ & 12 & 10 & 10.8 \\
$\begin{array}{c}\text { Maximum dry } \\
\text { density }(\mathrm{g} / \mathrm{cc})\end{array}$ & 1.714 & 1.780 & 1.856 \\
\hline
\end{tabular}

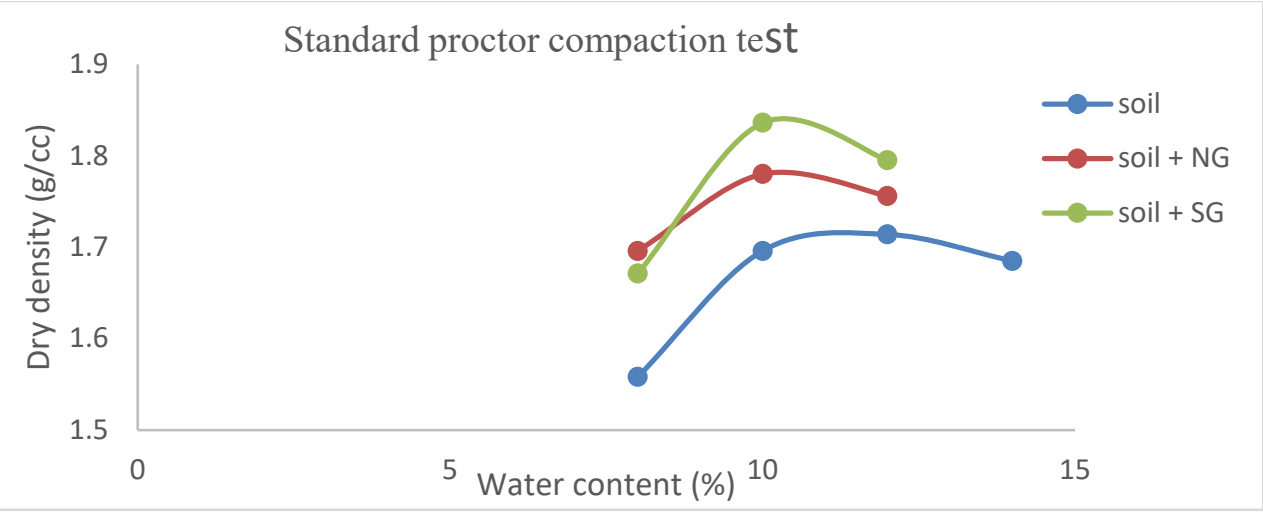

Fig 2. Relation between dry density and water content obtained by compaction test 


\section{California Bearing Ratio (CBR)}

CBR test samples were prepared with a predetermined water content which was obtained from the standard proctor compaction test. CBR test is used to find the bearing ratio of the sample under a gradual increase in pressure. According to ASTM D1883, the test procedure was carried out i.e., "Standard Test Method for CBR (California Bearing Ratio) of Laboratory-Compacted Soils" shown in Fig 3.The samples were placed in three layers with the unreinforced soil and tested. The results of CBR tests carried out in this study are tabulated in Table 5 and plotted in Fig. 4.
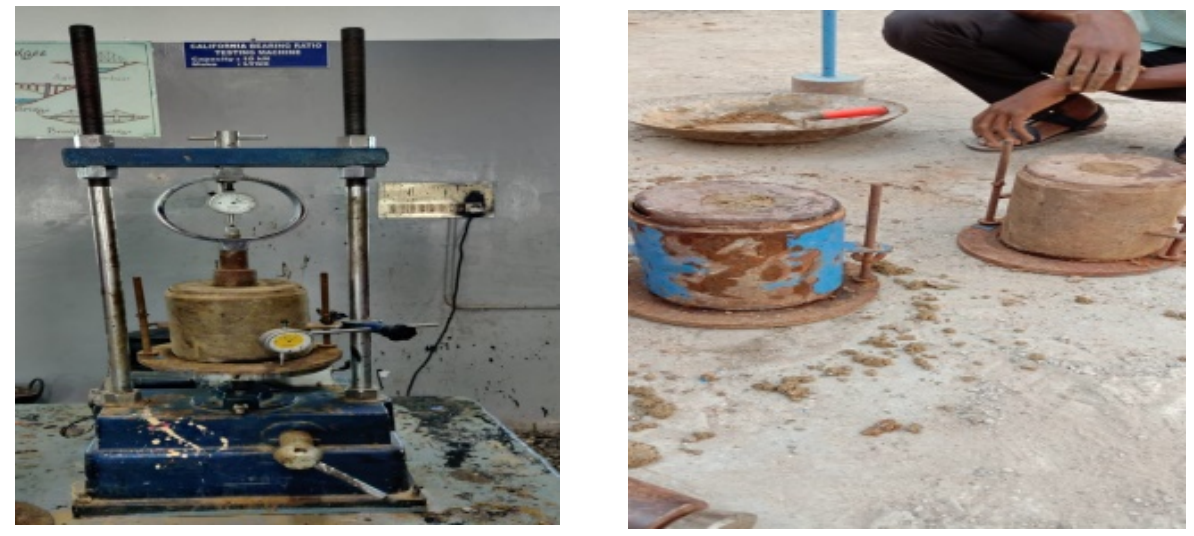

Fig 3. CBR test apparatus and CBR moulds

Table 5. Bearing ratios of different samples

\begin{tabular}{cccc}
\hline Properties $\backslash$ samples & $\begin{array}{c}\text { Unreinfo } \\
\text { rced soil }\end{array}$ & $\begin{array}{c}\text { Soil with natural } \\
\text { fibres }\end{array}$ & $\begin{array}{c}\text { Soil with synthetic } \\
\text { fibres }\end{array}$ \\
\hline $\begin{array}{c}\text { For 2.5mm penetration }- \\
\text { CBR (\%) }\end{array}$ & 2.26 & 4.015 & 2.55 \\
$\begin{array}{c}\text { For 5.0mm penetration }- \\
\text { CBR (\%) }\end{array}$ & 2.92 & 3.698 & 3.55 \\
\hline
\end{tabular}

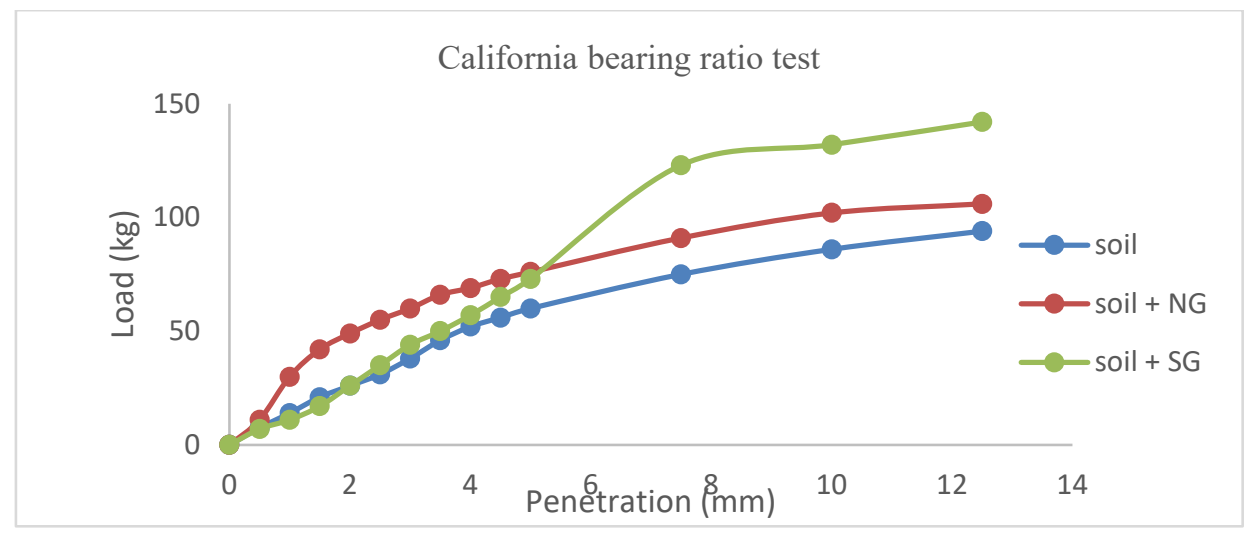

Fig 4. The load corresponding to penetration of different samples 


\section{Direct Shear Test}

This is the simple test that is used to determine the shearing strength of the different soil samples. This test was performed under two conditions are soil with natural fibres and soil with synthetic fibres.In the shear box the sample place in two layers and tested. The results from the shear test were tabulated in table 6 and the results were discussed in Table 6. Fig 5 show the stress difference between normal and shear.

Table 6. Angle of Shear resistance for different soil samples

\begin{tabular}{|c|c|c|c|}
\hline $\begin{array}{l}\text { Determination } \backslash \\
\text { samples }\end{array}$ & $\begin{array}{l}\text { Unreinforced } \\
\text { sample }\end{array}$ & $\begin{array}{l}\text { Soil with natural } \\
\text { fibres }\end{array}$ & $\begin{array}{c}\text { Soil with } \\
\text { synthetic fibres }\end{array}$ \\
\hline $\begin{array}{c}\text { Ultimate shear } \\
\text { angle }\end{array}$ & $\begin{array}{c}0^{0} 0^{\prime} \text { (for cohesive } \\
\text { soil) }\end{array}$ & $20^{0} 5^{\prime}$ & $43^{0} 9^{\prime}$ \\
\hline
\end{tabular}

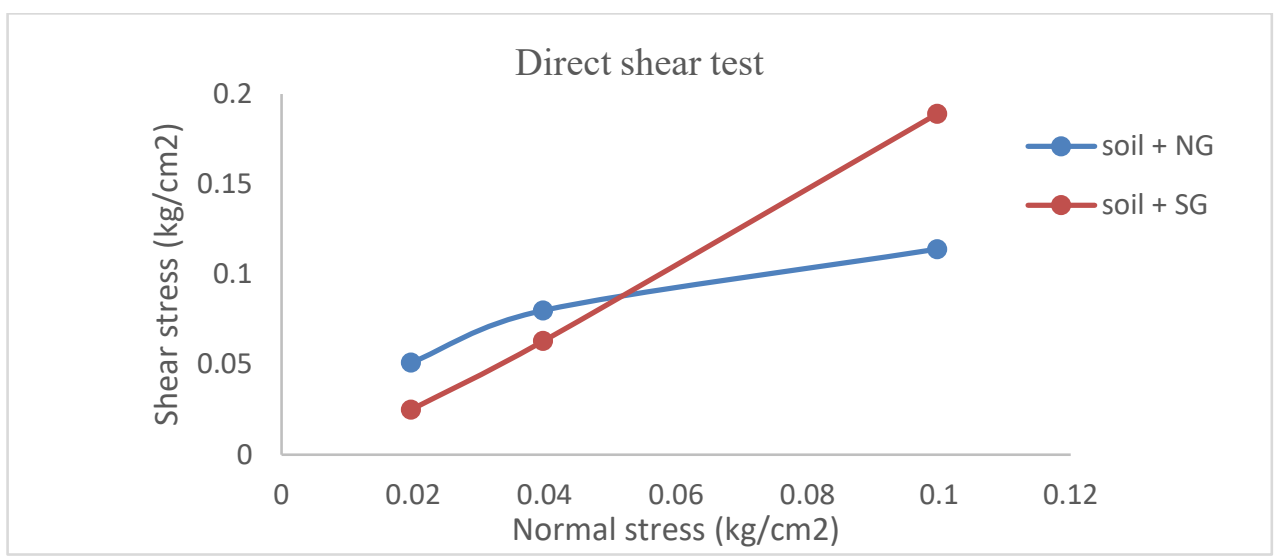

Fig 5. Relation between Direct shear test resulting graphs of different soil samples

\section{Conclusion}

This experimental study shows the effect of fibres addition on the geotechnical properties of the collected fine-grained soil. According to the results, the conclusion is as follows: Standard proctor compaction test results were obtained from the tests conducted on fine-grained soil by placing fibres sheet gives a reduction in optimum moisture content from $12 \%$ without fibres to $10 \%$ when carried out with natural fibres and $10.8 \%$ when carried out with artificial fibres and the maximum dry density was increasing with the addition of fibres, suggesting that the fibres inclusion is effective in improving soil failure ductility. Fine-grained soil is a cohesive soil that has zero angles of internal friction but when replaced with Natural and Artificial Fibres it possesses an angle of 20 05 ' and $4309^{\prime}$ 'respectively. The CBR values of soil with stabilized samples and soil without stabilized (unreinforced) sample shows that the increment in bearing capacity of the soil and makes it applicable for pavement. The stability of soil has been increased with reduction in optimum moisture when replaced with fibres gives wide applications of civil structures to be raised on fine-grained soil. 


\section{References}

[1] Murat azizozdemiR, Improvement in bearing capacity of a soft soil by addition of fly ash,Procedia Engineering, 143, 2016, 498-505. https://doi.org/10.1016/j.proeng.2016.06.063

[2] Ogundare D.A, Familusi A.O, Utilization of fibres for soil stabilization, American J Eng Research, 7(8), 2018, 224-231.

[3] B.Panigrahi, P.K. Pradhan, Improvement in bearing capacity of a soil by using natural geotextile, Int J Geo Eng, 10(9),2019, 1-12. https://doi.org/10.1186/s40703-019-0105-7

[4] Vivekkakdiya, Pushpendramisha, Soil stabilization using bamboo fibers, Int $\mathrm{j}$ Innovative tech, 5(11), 2019,436-440.

[5] Mahdi TaghipourMasoumi, Ali Abdi Kordani, Experimental study of geotextile effect on improving soil bearing capacity in aggregate surfaced roads, Int J Civil and Env Eng, 11, 2017, 43-49.

[6] Ajeet Rathee, Geetshivdasani, Shubham Sharma, Yash Sharma, Study on stabilization of soil using powdered glass, IJRET, 5(5), 2018 pp 1054-1056.

[7] Dhule S.B, Lalit jiremali, Shailesh shejwal, Sana Nasser, Kiran shejwal, Leena wanare, Study on stabilization of soil using stone dust, IJRET, 6(5), 2019, 815-828.

[8] Anjanadevi K.A, Azharrahman A.R, Merine George, Soil stabilization using jute and human hair fiber, IRJET, 6(5), 2019, 5117-5121.

[9] Sunil, Akash batra, Pappu Sharma, Sohanlal, Soil stabilization by using jute fiber, IRJET, 6(3), 2019, 8209-8212.

[10] Ankit Yaduvansh, Ankur tayal, Aman bhatnagar, Varun Aggarwal, Plastic as a soil stabilizer, IRJET 6(4),2019, 4866- 4870.

[11] B.Priyadharshini, M.Kavisri, Utilization of textile sludge in manufacturing e-bricks, Int J Civil Eng and Tech, 9(11), 2018, 2266-2273.

[12] Sridhar Rajagopalaiah, A Review on Improvement of Subgrade Soil Using Coir Geotextile2019, Springer international publishing, 2014.

[13] Mahuya Ghosh, P.K. Choudhury and Tapobrata Sanyal, Suitability of Natural Fibres in Geotextile Applications, IGC 2009, Indian geotechnical Society, 2009.

[14] N F Bawadi, N S Ahmad, A F Mansor, S A Anuarl and M A Rahim, Effect of natural fibers on the soil compaction characteristics, IOP Conf. Series: Earthand Environmental Science 476, 2020 012043. https://doi.org/10.1088/1755-1315/476/1/012043

[15] Jian Li, Chaosheng Tang, Deying Wang, Xiangjun Pei, Bin Shi, Effect of discrete fibre reinforcement on soil tensile strength,J Rock Mech and Geo Eng 6(2), 2014, 133-137.

https://doi.org/10.1016/j.jrmge.2014.01.003

[16] Kavisri M,Sathish S, B.Priyadharshini, Experimental Studies on Properties of Self-Compacting Concrete by Partial Replacement of Cement by Industrial Waste Red Mud and Slag, Indian J Env Protection, 39(10),2019, 902-904. 